\title{
Copper, nickel and zinc contamination in soils within the precincts of mining and landfilling environments
}

\author{
V. M. Ngole • G. I. E. Ekosse
}

Received: 31 January 2011/Revised: 8 August 2011/Accepted: 24 November 2011/Published online: 24 April 2012

(c) CEERS, IAU 2012

\begin{abstract}
This study determined copper, nickel and zinc concentrations in soils within the precincts of a coppernickel mining and urban landfilling environments, and used obtained values to appraise the degree of soil contamination and pollution based on geoaccumulation index, contamination factor and pollution load index. Mean concentrations of copper $(252.4 \mathrm{mg} / \mathrm{kg})$, nickel $(153.0 \mathrm{mg} /$ $\mathrm{kg})$ and zinc $(30.4 \mathrm{mg} / \mathrm{kg})$ in soils around the mining area were considerably higher than those around the landfill (4.3, 0.91, and $13.7 \mathrm{mg} / \mathrm{kg}$, respectively, for copper, nickel and zinc). The mining area was moderate to heavily contaminated with copper, nickel and zinc $\left(1<I_{\text {geo }}<4\right)$, whereas the landfill area was moderately contaminated $\left(1<I_{\text {geo }}<3\right)$. In both areas, the level of copper contamination was higher than that of nickel and zinc. Contamination around the mining environment was attributed to mining activities whereas around the landfill area, migration of leachate from the disposed waste could have been responsible.
\end{abstract}

Keywords Contamination factor - Dead zones · Geoaccumulation index $\cdot$ Leachate .

Pollution load index

\section{M. Ngole $(\square)$}

Faculty of Science, Engineering and Technology,

Walter Sisulu University, Private Bag X1, Mthatha 5117,

Eastern Cape Province, South Africa

e-mail: vm.ngole@gmail.com

\section{G. I. E. Ekosse}

Directorate of Research Development,

Walter Sisulu University, Private Bag X1, Mthatha 5117,

Eastern Cape Province, South Africa

\section{Introduction}

Soils play an important role in ecological stability but their quality with regards to the concentrations of heavy metals may be compromised by several anthropogenic activities. Mining and waste disposal are two of the anthropogenic activities that have contributed to increased levels of heavy metals, including copper $(\mathrm{Cu})$, nickel $(\mathrm{Ni})$ and zinc $(\mathrm{Zn})$ in soils. The occurrences of $\mathrm{Cu}-, \mathrm{Ni}-$ and $\mathrm{Zn}$ - sulphidic ores (Barrie et al. 2008), and their mining and processing have often resulted in mine waste rich in these heavy metals which eventually find their way into surrounding environments (Ekosse et al. 2004; Schippers et al. 2007). Copper and Zn are micronutrients of plants but at high concentrations, they become phytotoxic (Yruela et al. 2000; Nicholls and Mal 2003). Nickel may be essential for higher plants including potatoes (Solanum tuberosum), soybean (Glycine max L), cowpeas (Vigna unguiculata L. Walp), tomato (Lycopersicon esculentum L.) and barley (Hordeum vulgare L.) where it has been shown to prevent urea accumulation, but its metabolic role is yet to be established in many plants (Brown et al. 1987; Bai et al. 2006; Kabata-Pendias and Mukherjee 2007). Increased concentrations of $\mathrm{Cu}, \mathrm{Ni}$, and $\mathrm{Zn}$ above the maximum allowable limit (MAL) of 100, 100 and $300 \mathrm{mg} /$ $\mathrm{kg}$, respectively (Kabata-Pendias 1995), in soils may present health risk to plants, animals and human beings. Mining activities around the Selebi Phikwe Cu-Ni mine in Botswana is contributing to elevated concentrations of $\mathrm{Cu}, \mathrm{Ni}$ and $\mathrm{Zn}$ in soils around the area (Ekosse et al. 2004, 2005). Acid mine drainage (AMD) generating tailings dam consisting of waste from the processing of $\mathrm{Cu}-, \mathrm{Ni}$-, and $\mathrm{Zn}$ - sulphidic ores at Selebi-Phikwe, Botswana (Schippers et al. 2007) could be yielding high concentrations of the heavy metals. The high Gross Domestic Product (GDP) of Botswana derived from mining has contributed to rapid urbanisation and improved 
occidental life styles, which have led to a very noticeable increase in waste generation. The manner in which the generated waste is disposed may be having an effect on surrounding soils and human health (Ekosse et al. 2004, 2005)

Waste disposal is therefore one of the challenges that Botswana is facing. Considering that $\mathrm{Cu}, \mathrm{Ni}$ and $\mathrm{Zn}$ are widely used by man including the people of Botswana for different purposes such as the manufacture of cleaning products, and are contained in cosmetics and shampoos, paints and pigments, and lubricants (Alloway and Ayres 1997; European Commission 2001), they are found in most municipal solid waste, and consequently in leachate derived from municipal solid waste landfills. Concentration ranges of $25-215 \mathrm{mg} / \mathrm{kg} \mathrm{Cu}, 7-21 \mathrm{mg} / \mathrm{kg} \mathrm{Ni}$, and $400-655 \mathrm{mg} / \mathrm{kg}$ $\mathrm{Zn}$ have been reported in municipal wastes (Purves 1973). Christensen et al. (1996) determined $10 \mu \mathrm{g} / \mathrm{l} \mathrm{Cu}, 10 \mu \mathrm{g} / \mathrm{l} \mathrm{Ni}$, and $100 \mu \mathrm{g} / \mathrm{Zn}$ in leachate from the Grinstead landfill in Denmark. Migration of leachate from the Gaborone landfill into surrounding soils may result in heavy metal accumulation in the soils and consequently their uptake by herbage.

Prior to the establishment of both the mine and the landfill, appropriate environmental impact assessment (EIA) studies, which could have given direction on the containment of soil contamination and soil pollution control were not conducted. But non substantiated reports based on general observations from residents of the vicinities of the mining and landfilling environments indicated that the soils were polluted. The Gaborone Landfill, designed to receive municipal waste from Gaborone City and neighboring areas, has also served as an unconventional industrial waste landfill. The landfill was not lined, and the waste is not compacted and covered as per the requirements of an engineered landfill. These shortcomings have opportuned heavy metals-rich leachate migrating into the surrounding environment of the landfill. Similar to the landfill, is the mining environment at Selebi Phikwe where it is believed the soil heavy metal concentrations have increased as a result of their migration into the soils from tailings dump, and deposition of heavy metals contaminated particulate air matter (PAM) (Ekosse et al. 2004, 2005). Studies were carried out in 2008 to investigate the degree of contamination of $\mathrm{Cu}, \mathrm{Ni}$ and $\mathrm{Zn}$ in soils around the Selebi Phikwe $\mathrm{Cu}-\mathrm{Ni}$ mine and the Gaborone landfill both located in Botswana.

\section{Material and method}

Study areas

Botswana is located in Southern Africa and is surrounded by South Africa, Namibia, Zimbabwe and Zambia. Selebi
Phikwe located at $27^{\circ} 47^{\prime} \mathrm{E}-27^{\circ} 53^{\prime} \mathrm{E}$, and $22^{\circ} 55^{\prime} \mathrm{S}-22^{\circ} 00^{\prime} \mathrm{S}$ (Fig. 1) is a mining town, and Gaborone city located at $24^{\circ} 35^{\prime} \mathrm{S}-24^{\circ} 45^{\prime} \mathrm{S}$ and $25^{\circ} 51^{\prime} \mathrm{E}-29^{\circ} 59^{\prime} \mathrm{E}$ (Fig. 1) is the most urbanised city in the country. Both Selebi Phikwe and Gaborone have semi-arid climate. The climate of Selebi Phikwe is distinguished by an annual rainfall of about $450 \mathrm{~mm}, 90 \%$ of which occurs between the months of October and April; and temperatures ranging from 18 to $35{ }^{\circ} \mathrm{C}$ with highest values recorded during the months between October and April (Bhalotra 1987; Potenhaner 1994). Gaborone has an annual rainfall average of 250-450 $\mathrm{mm}$ and temperatures range from $5{ }^{\circ} \mathrm{C}$ in July (midwinter) to $33{ }^{\circ} \mathrm{C}$ in January (summer) (Khupe 1996). The soils within the surroundings of the Selebi Phikwe mine are classified as eutric regosols and haplic luvisols (Soil Mapping and Advisory Service Project 1990).

The Gaborone Landfill site, which measures $630 \mathrm{~m}$ from north to south and about $340 \mathrm{~m}$ from east to west lies on a gentle slope which falls from $984 \mathrm{~m}$ on the western corner to $975 \mathrm{~m}$ on the southern and eastern corners (Arup Botswana 1993). The site is overlain by the Thamaga Granite of the Gaborone Granite Complex and is mineralogically dominated by quartz, hematite muscovite, plagioclase, and microcline (Ngole and Ekosse 2006). Soils of the Gaborone landfill area are described as calcic luvisols (Soil Mapping and Advisory Service Project 1990) with quartz, microcline, albite, muscovite, kaolinite and smectites constituting the mineral assemblage (Ngole et al. 2004; Ngole and Ekosse 2006). According to Arup Botswana (1993) groundwater beneath the site varies between 4.48 and $7.86 \mathrm{~m}$ below the existing ground surface. The permeability of the soils in the landfill environment varies between $5 \times 10^{-11}$ and $2 \times 10^{-5} \mathrm{~m} / \mathrm{s}$ (Arup Botswana 1993).

\section{Sampling of soils}

Ten sampling areas including a control site located about $56 \mathrm{~km}$ from Selebi Phikwe were selected to assess the effect of mining on the concentrations of $\mathrm{Cu}, \mathrm{Ni}$ and $\mathrm{Zn}$ in soils around the area. The location and characteristics of these sites are given in Table 1. The soil lithology of the control site was similar to that of Selebi Phikwe area. Soil samples were collected twice monthly between January and July from the different sites. A total of 140 soil samples were collected from the Selebi Phikwe mining area for analyses. At the landfilling environment, soil samples were collected from ten different sites (P2-P11) around the landfill and a control site (P1) located $6 \mathrm{~km}$ away from the landfill. The locations of the sampling points in relation to the landfill are as described in Table 1. Sampling points P2-P11 were located within $20 \mathrm{~m}$ of the landfill boundary. A total of 22 soil samples from the landfill vicinity were analysed for the study. 


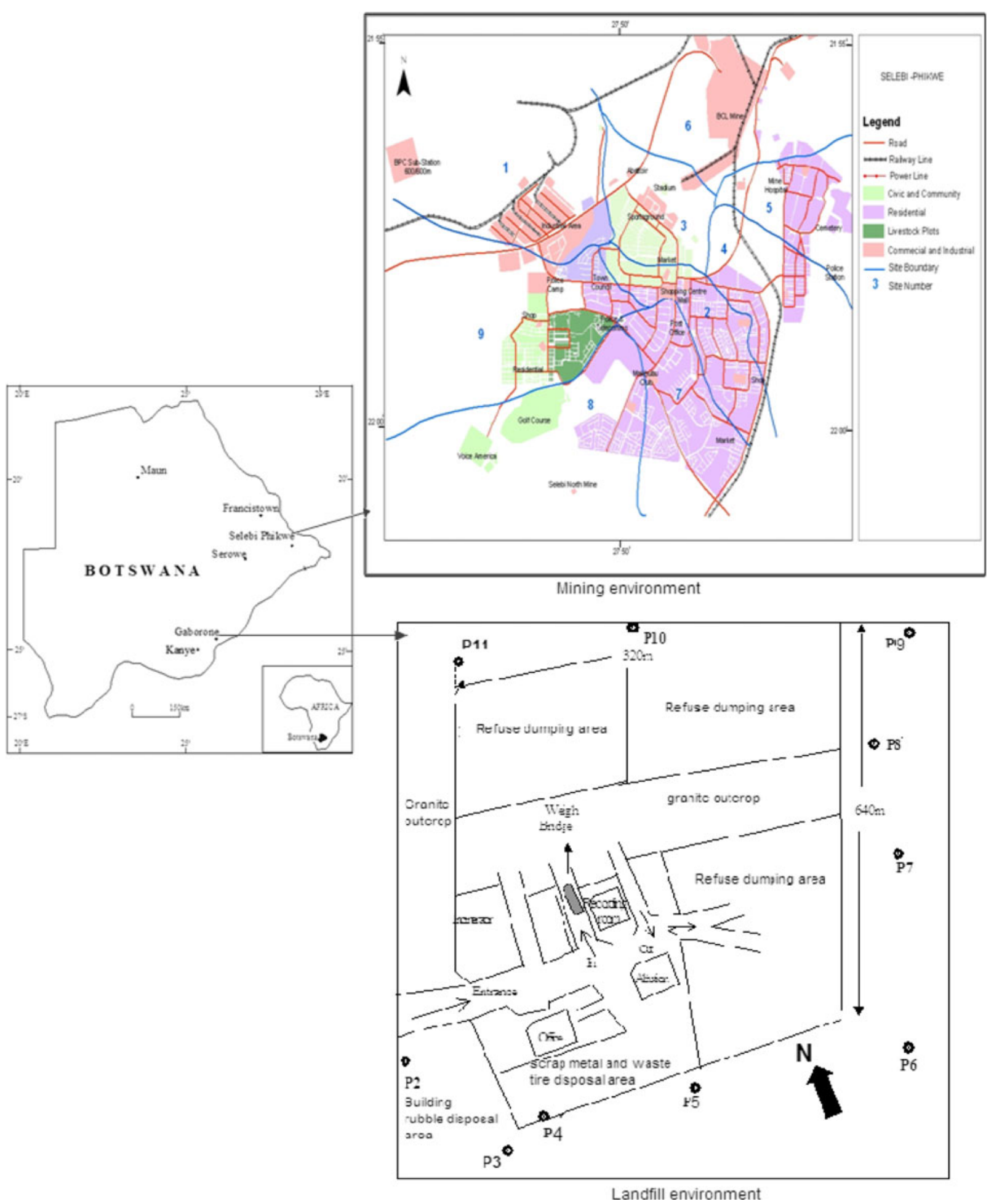

Fig. 1 Location map of the miming and landfilling environments

Elemental analyses

One gram of each soil sample from the mining and landfilling environments was digested in $6 \mathrm{M} \mathrm{HNO}_{3}$ for $7 \mathrm{~h}$ at $50{ }^{\circ} \mathrm{C}$ (Singh et al. 1999; Sheppard et al. 2000). The concentrations of $\mathrm{Cu}, \mathrm{Ni}$ and $\mathrm{Zn}$ in the different extracts were determined with a Varian Zeeman GTA 96 Plus Graphite Furnace whereas that of $\mathrm{Zn}$ was determined with a Varian Spectra AA-220 FS atomic absorption spectrometer after acid digestion. All samples were analysed in duplicate and the mean value reported as the concentration value for the metal. 
Table 1 Location/characteristics of sampling sites at the mining and landfilling environments

\begin{tabular}{|c|c|c|c|c|c|}
\hline \multicolumn{3}{|c|}{ Mining environment } & \multicolumn{3}{|c|}{ Land filling environment } \\
\hline $\begin{array}{l}\text { Sampling } \\
\text { site }\end{array}$ & $\begin{array}{l}\text { Distance of site } \\
\text { from mine and } \\
\text { smelter/ } \\
\text { concentrator plant } \\
(\mathrm{km})\end{array}$ & Location/characteristics & $\begin{array}{l}\text { Sampling } \\
\text { site }\end{array}$ & $\begin{array}{l}\text { Distance of } \\
\text { site from } \\
\text { landfill } \\
\text { boundary } \\
\text { (m) }\end{array}$ & Location/characteristics \\
\hline 1 & 1.7 & $\begin{array}{l}\text { Industrial area }(150 \mathrm{~m} \text { after the } \\
\text { railway crossing) }\end{array}$ & $\mathrm{P} 1$ & 6,000 & Control site \\
\hline 2 & 1.6 & $\begin{array}{l}\text { Bosele hotel (commercial area) and } \\
\text { new township }\end{array}$ & $\mathrm{P} 2$ & 10 & $\begin{array}{l}\text { South western corner of landfill close to } \\
\text { area of building and demolition waste } \\
\text { disposal }\end{array}$ \\
\hline 3 & 1.3 & $\begin{array}{l}\text { Between the township stadium and } \\
\text { the mine (behind the Botswana } \\
\text { power corporation) }\end{array}$ & P3 & 15 & $\begin{array}{l}\text { South western corner of landfill close to } \\
\text { area of building and demolition waste } \\
\text { are disposal and a leachate plume }\end{array}$ \\
\hline 4 & 1.2 & $\begin{array}{l}\text { Between the township boundary and } \\
\text { the railway line (directly behind a } \\
\text { community junior secondary } \\
\text { school) }\end{array}$ & P4 & 10 & $\begin{array}{l}\text { Southern corner of the landfill close to } \\
\text { where waste tyres and scrap metals are } \\
\text { disposed }\end{array}$ \\
\hline 5 & 1 & $\begin{array}{l}\text { Opposite the mine hospital, close to } \\
\text { old township }\end{array}$ & P5 & 10 & \\
\hline 6 & 0.5 & $\begin{array}{l}\text { Between the mine and explosive } \\
\text { storage facilities (close to old } \\
\text { township) }\end{array}$ & P6 & 12 & $\begin{array}{l}\text { Eastern corner of the landfill where } \\
\text { municipal waste, garden waste and waste } \\
\text { from commercial centers are disposed }\end{array}$ \\
\hline 7 & 6 & $\begin{array}{l}\text { Towards the airport (about } 250 \mathrm{~m} \\
\text { from the Airport-Sefophe-Selebi } \\
\text { Phikwe road juncture) }\end{array}$ & $\mathrm{P} 7$ & 14 & $\begin{array}{l}\text { and where leachate plume had been } \\
\text { identified }\end{array}$ \\
\hline 8 & 7 & $\begin{array}{l}\text { Off untarred road leading to the } \\
\text { Selebi North mine (100 m out of } \\
\text { old township boundary, adjacent } \\
\text { to the new township) }\end{array}$ & P8 & 13 & \\
\hline 9 & 8 & $\begin{array}{l}\text { The penultimate bridge before } \\
\text { entering into the Selebi Phikwe } \\
\text { township }\end{array}$ & P9 & 13 & \\
\hline \multirow[t]{2}{*}{10} & 56 & $\begin{array}{l}\text { Control site located close to the road } \\
\text { juncture leading to Selebi Phikwe } \\
\text { from the Gaborone-Francistown } \\
\text { main road }\end{array}$ & $\mathrm{P} 10$ & 9 & $\begin{array}{l}\text { Northern corner of the landfill where } \\
\text { waste, garden waste and waste from } \\
\text { commercial centers and institutions are } \\
\text { disposed }\end{array}$ \\
\hline & & & P11 & 10 & \\
\hline
\end{tabular}

\section{Data interpretation}

The degree of $\mathrm{Cu}, \mathrm{Ni}$ and $\mathrm{Zn}$ contamination of the samples was assessed using geoaccumulation index $\left(I_{\text {geo }}\right)$ proposed by Muller (1969) and contamination factor (CF) used by Hakanson (1980). $I_{\text {geo }}$ and CF have been widely used (Akoto et al. 2008; Agunbiade and Fawale 2009; Šmuc et al. 2009; Seshan et al. 2010) to evaluate heavy metal contamination in terrestrial, aquatic, and marine environments. The formula used to determine $I_{\text {geo }}$ is indicated in Eq. 1.

$I_{\text {geo }}=\log _{2} \frac{c_{n}}{1.5 \times B_{n}}$

where $C_{n}=$ measured concentration of heavy metal in the soil
$B_{n}=$ geochemical background concentration of the same heavy metal

1.5 = background matrix correction factor due to lithogenic effect.

Contamination factors of $\mathrm{Cu}, \mathrm{Ni}$ and $\mathrm{Zn}$ in the soil samples were determined as indicated in Eq. 2.

$$
\mathrm{CF}=\frac{C_{\mathrm{m}}}{B_{\mathrm{m}}}
$$

where $C_{\mathrm{m}}$ is the measured concentration of heavy metal in the soil

$B_{\mathrm{m}}=$ local background concentration value of the heavy metal. 
Table 2 Classification of geoaccumulation index and contamination factor values

\begin{tabular}{ll}
\hline$I_{\text {geo }}$ classes & CF classes \\
\hline$I_{\text {geo }}<0$ - uncontaminated & $\mathrm{CF}<1$-low contamination \\
$0<I_{\text {geo }}<1$-moderately & $1<\mathrm{CF}<3$ moderate \\
$\quad$ contaminated & contamination \\
$1<I_{\text {geo }}<3$-moderately to heavily & $3<\mathrm{CF}<6$ considerable \\
contaminated & contamination \\
$3<I_{\text {geo }}<4$-heavily contaminated & $\mathrm{CF}>6$ - very high \\
& contamination \\
$4<I_{\text {geo }}<5$-heavily to extremely & \\
contaminated & \\
$I_{\text {geo }}>5$ - extremely contaminated. & \\
\hline
\end{tabular}

In this study, the concentrations of the heavy metals in the control samples were used as the background concentration values to determine both $I_{\text {geo }}$ and CF. Interpretation of $I_{\text {geo }}$ and CF were done according to the classes described by Ji et al. (2008); Agunbiade and Fawale (2009); and Seshan et al. (2010), and are explained in Table 2.

To assess the extent of pollution of these soils by $\mathrm{Cu}, \mathrm{Ni}$ and $\mathrm{Zn}$, the formula used by Seshan et al. (2010) was employed where pollution load index (PLI) was calculated as indicated in Eq. 3.

$\mathrm{PLI}=n \sqrt{\mathrm{CF}_{\mathrm{Cu}} \times \mathrm{CF}_{\mathrm{Ni}} X \mathrm{CF}_{\mathrm{Zn}}}$

where $\mathrm{CF}=$ contamination factor

$n=$ number of elements (in this case 3 )

PLI values $<1$ indicate no pollution whereas values $>1$ indicate pollution.

\section{Results and discussion}

Concentrations of copper, nickel and zinc in the soils

The concentration values obtained for $\mathrm{Cu}$ in the soils from around the mining environment were significantly higher than those obtained from around the landfill with concentration values ranging from $83-372 \mathrm{mg} / \mathrm{kg}$ and $0.9-10.7 \mathrm{mg} /$ $\mathrm{kg}$ for $\mathrm{Cu}$ in soils from the mining and landfill environments, respectively (Table 3 ). For both environments, $\mathrm{Cu}$ concentration in the soils was higher than those at the control sites. Soil $\mathrm{Cu}$ concentrations decreased with distance from the smelter/concentrator plant with sites 4, 5 and 6 having the highest values (Fig. 2). Soils from sites P8, P9 and P10 had the highest concentration of $\mathrm{Cu}$ around the landfill environment (Table 3).

A decrease in concentration of $\mathrm{Cu}$ and $\mathrm{Ni}$ with distance was observed in the mining area (Fig. 2a) whereas in the landfill environment, no specific trend was observed in the
Table 3 Mean concentration of copper, nickel, and zinc in soil samples from Selebi Phikwe mining and Gaborone landfill environments

\begin{tabular}{|c|c|c|c|c|c|c|c|}
\hline \multirow[t]{2}{*}{$\begin{array}{l}\text { Site } \\
\text { no. }\end{array}$} & \multicolumn{3}{|c|}{$\begin{array}{l}\text { Selebi Phikwe mining } \\
\text { environment }\end{array}$} & \multirow[t]{2}{*}{$\begin{array}{l}\text { Site } \\
\text { no. }\end{array}$} & \multicolumn{3}{|c|}{$\begin{array}{l}\text { Gaborone landfilling } \\
\text { environment }\end{array}$} \\
\hline & $\begin{array}{l}\mathrm{Cu} \\
(\mathrm{mg} / \\
\mathrm{kg})\end{array}$ & $\begin{array}{l}\mathrm{Ni} \\
(\mathrm{mg} / \\
\mathrm{kg})\end{array}$ & $\begin{array}{l}\mathrm{Zn} \\
(\mathrm{mg} / \\
\mathrm{kg})\end{array}$ & & $\begin{array}{l}\mathrm{Cu} \\
(\mathrm{mg} / \\
\mathrm{kg})\end{array}$ & $\begin{array}{l}\mathrm{Ni} \\
(\mathrm{mg} / \\
\mathrm{kg})\end{array}$ & $\begin{array}{l}\mathrm{Zn} \\
(\mathrm{mg} / \\
\mathrm{kg})\end{array}$ \\
\hline 1 & 244.4 & 155.0 & 44.3 & P1 & 1.3 & 0.2 & 5.8 \\
\hline 2 & 250.8 & 163.0 & 43.6 & P2 & 3.1 & 0.8 & 5.6 \\
\hline 3 & 248.1 & 170.3 & 33.1 & P3 & 4.0 & 1.2 & 9.0 \\
\hline 4 & 311.9 & 266.6 & 26.3 & P4 & 3.2 & 1.1 & 10.2 \\
\hline 5 & 353.6 & 230.5 & 38.1 & P5 & 4.6 & 1.1 & 11.4 \\
\hline 6 & 371.6 & 173.1 & 22.2 & P6 & 2.2 & 0.8 & 11.0 \\
\hline 7 & 270.5 & 105.9 & 20.6 & P7 & 2.2 & 1.0 & 14.8 \\
\hline 8 & 136.5 & 66.6 & 22.2 & P8 & 6.3 & 1 & 28.4 \\
\hline 9 & 83.9 & 45.8 & 22.9 & P9 & 10.7 & 1.1 & 16.4 \\
\hline \multirow[t]{2}{*}{10} & 20.0 & 22.3 & 25.5 & P10 & 5.7 & 0.6 & 15.1 \\
\hline & & & & P11 & 0.9 & 0.4 & 15.5 \\
\hline
\end{tabular}

concentration of $\mathrm{Cu}$ and $\mathrm{Ni}$ as the distance from the landfill increased (Fig. 2b).

The $R^{2}$ value for the relationship between distance from the mine and $\mathrm{Cu}$ and $\mathrm{Ni}$ concentration in the soils (Fig. 2a) indicates that up to 70 and $77 \%$ of the variations in concentrations of $\mathrm{Cu}$ and $\mathrm{Ni}$, respectively, in the soils can be explained by distance from the mine. This trend may be explained by the deposition of larger amounts of heavy metals rich PAM in areas closer to the mine (Ekosse et al. 2004). $R^{2}$ values for $\mathrm{Zn}$ in soils from both the mine and landfill environment and $\mathrm{Cu}$ and $\mathrm{Ni}$ in soils from landfill environment showed little correlation with distance (Fig. 2b) as $<6 \%$ of the variations of the concentrations in these metals in the soils could be attributed to their distance from the mine and landfill sites. Lack of a defined pattern in concentrations of heavy metals with distance from the Gaborone landfill could be explained by the topography of the landfill, which offers preferential routes for leachate migration from the landfill. Similar results have been obtained by Chuangcham et al. (2008) where concentrations of metals around a landfill were influenced by the direction of flow of surface drainage rather than the distance from the landfill. Within these leachate flow routes however, the concentrations of these metals in the soils may decrease with distance from the landfill due to sorption by the soil.

Geoaccumulation index of copper, nickel and zinc in the soils

Based on $I_{\text {geo }}$ values, sites 1-7 within the mining environment were heavily contaminated for $\mathrm{Cu}\left(3<I_{\text {geo }}<4\right)$ whereas sites 8 and 9 were moderately to heavily 

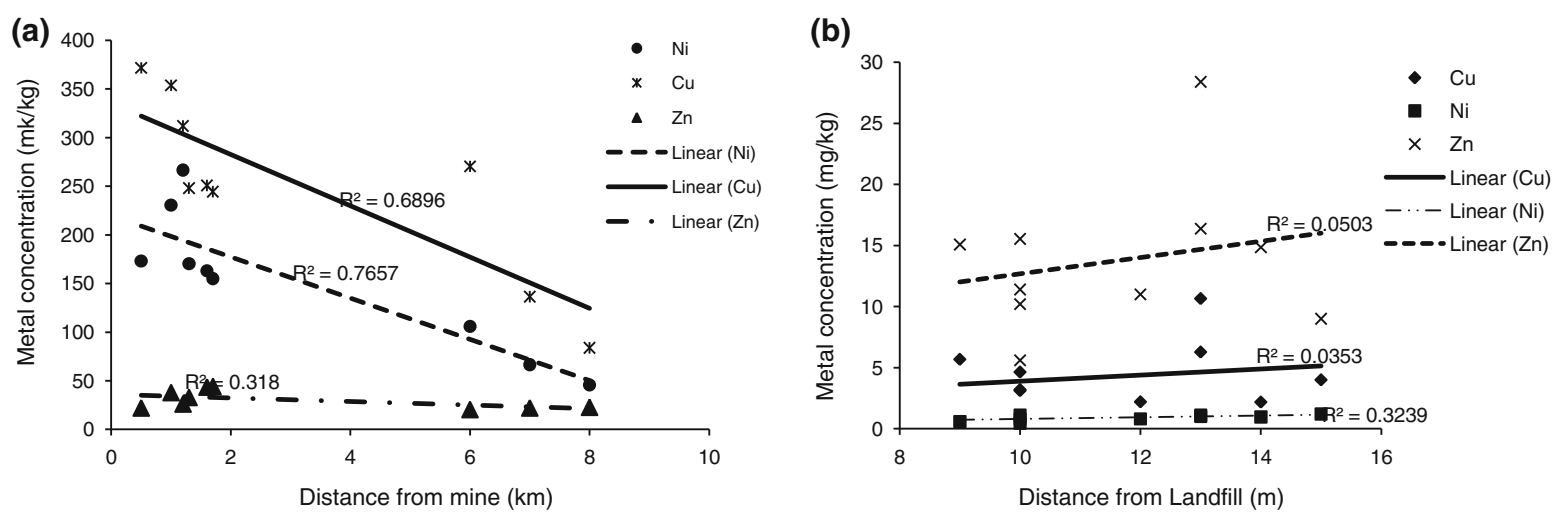

Fig. 2 Trend of heavy metal concentrations with distance from the mine (a) and landfill (b)

contaminated $\left(1<I_{\text {geo }}<3\right)$ (Fig. 3a1). All sites within the landfill environment were moderately to heavily $\mathrm{Cu}$ contaminated $\left(1<I_{\text {geo }}<3\right)$ (Fig. 3a2). The $I_{\text {geo }}$ values obtained for $\mathrm{Ni}$ in the soils within the mining environment indicated that the soils were moderately to heavily contaminated $\left(1<I_{\text {geo }}<3\right)$; unlike soils within the landfill environment which were described as uncontaminated to moderately contaminated $\left(0<I_{\text {geo }}<1\right)$. The highest $I_{\text {geo }}$ value for $\mathrm{Ni}$ within the mining environment was obtained at site 4 whereas around the landfill environment, it was at P3 (Fig. 3b1 and b2). Only site P9 on the eastern corner of the landfill could be described as moderate to heavily contaminated $\left(1<I_{\text {geo }}<3\right)$ for $\mathrm{Ni}$ (Fig. 3b2). In both environments, the soils were uncontaminated for $\mathrm{Zn}$ as depicted by $I_{\text {geo }}$ values which were all $<1$, except at P8 where the value was 1.7 (Fig. $3 \mathrm{c} 1$ and $\mathrm{c} 2$ ). The soils within the Selebi Phikwe area are generally rich in $\mathrm{Cu}$ and $\mathrm{Ni}$ due to the geological nature of the surrounding $\mathrm{Cu}-\mathrm{Ni}$ bearing rocks (Nkoma and Ekosse 1999; Ekosse et al. 2003a). Higher concentrations of $\mathrm{Cu}$ and $\mathrm{Ni}$ in the soils within the mining environment could have emanated from the exploitation of the $\mathrm{Cu}-\mathrm{Ni}$ orebodies. Low values of $\mathrm{Cu}$ and $\mathrm{Ni}$ obtained for soils around the landfill environment may be due to low background lithogenic values of the granitic surrounding rocks (Zhai et al. 2003). In soils at the landfill area, $\mathrm{Cu}$ and $\mathrm{Ni}$ concentrations were most likely influenced by leachate from the landfill. This explanation ascertains the higher values of $\mathrm{Cu} I_{\text {geo }}$ and $\mathrm{Ni} I_{\text {geo }}$ within the mining environment compared with the landfilling environment (Fig. $3 b 1$ and b2).

Zinc is a component of paint pigments, steel products, metal, automotive parts, roofings, packaging materials (Alloway 2005), cleaning and food products (European Commission 2001). Purves (1973) in a study of heavy metals content of municipal wastes reported $\mathrm{Zn}$ concentration range of $400-655 \mathrm{mg} / \mathrm{kg}$. Zinc is therefore likely to be contained in municipal solid waste leachate. The occurrence of $\mathrm{Zn}$ in the Gaborone landfill is therefore not unexpected. Lower concentrations of $\mathrm{Zn}$ in the $\mathrm{Cu}-\mathrm{Ni}$ mining area can be explained by low concentrations of $\mathrm{Zn}$ in $\mathrm{Cu}-\mathrm{Ni}$ ore bodies and their host rock (Nsouli et al. 2004).

Contamination factor of copper, nickel and zinc in the soils

Values of contamination factor (CF) for soils within the mining environment indicated that sites $1-8$ had a high degree of contamination with regards to $\mathrm{Cu}(\mathrm{CF}>6)$ (Fig. 4a1). The CF values for Ni (Fig. 4b1) indicated that sites 1-6 had high Ni contamination ( $\mathrm{CF}>6$ ) whereas sites 7 and 8 had considerable contamination $(3<\mathrm{CF}<6)$. Nickel contamination around site 9 was moderate $(1<\mathrm{CF}<3)$. The $\mathrm{CF}$ values for $\mathrm{Zn}$ for sites $1-5$ were $<3$ (indicating moderate contamination) and those of sites 6-7 were $<0$, indicating low contamination (Fig. $4 \mathrm{c} 1$ ). In soils within the landfilling environment, $\mathrm{CF}$ values for P11 indicated a low degree of $\mathrm{Cu}$ contamination $(\mathrm{CF}<1)$, whereas at sites $\mathrm{P} 2, \mathrm{P} 4, \mathrm{P} 6$ and $\mathrm{P} 7, \mathrm{Cu}$ contamination was of moderate degree $(1<\mathrm{CF}<3)$ (Fig. 4a2). Sites P3, P5, P8 and P10 had considerable degree of $\mathrm{Cu}$ contamination $(3<\mathrm{CF}<6)$ and site $\mathrm{P9}$, a high degree of $\mathrm{Cu}$ contamination $(\mathrm{CF}>6)$ (Fig. 4a2). Within the precincts of the landfill, Ni contamination was higher than that of $\mathrm{Cu}$ with $\mathrm{Ni} \mathrm{CF}$ values for $\mathrm{P} 2-$ P9 indicating considerable contamination $(3<\mathrm{CF}<6)$, and that at $\mathrm{P} 10$ and $\mathrm{P} 11$, moderate contamination $(1<\mathrm{CF}<3)$ (Fig. 4b2). Zinc contamination within the landfill environment was higher than that within the mining environment as indicated by $\mathrm{CF}$ values (Fig. 4c2). Zn CF around the landfill was highest at P8 and lowest at P2. With a $\mathrm{CF}$ value of $0.97, \mathrm{P} 2$ can be described as having low $\mathrm{Zn}$ contamination, whereas P3, P4, P5, P6, P7, P9, P10 and P11 can be described as having moderate $\mathrm{Zn}$ Contamination.

The mining and processing of sulphide minerals at Selebi Phikwe resulted in the production of mine waste 
Fig. 3 Geoaccumulation indices of copper (a), nickel (b) and zinc (c) in soils within the mining (1) and landfilling (2) environments
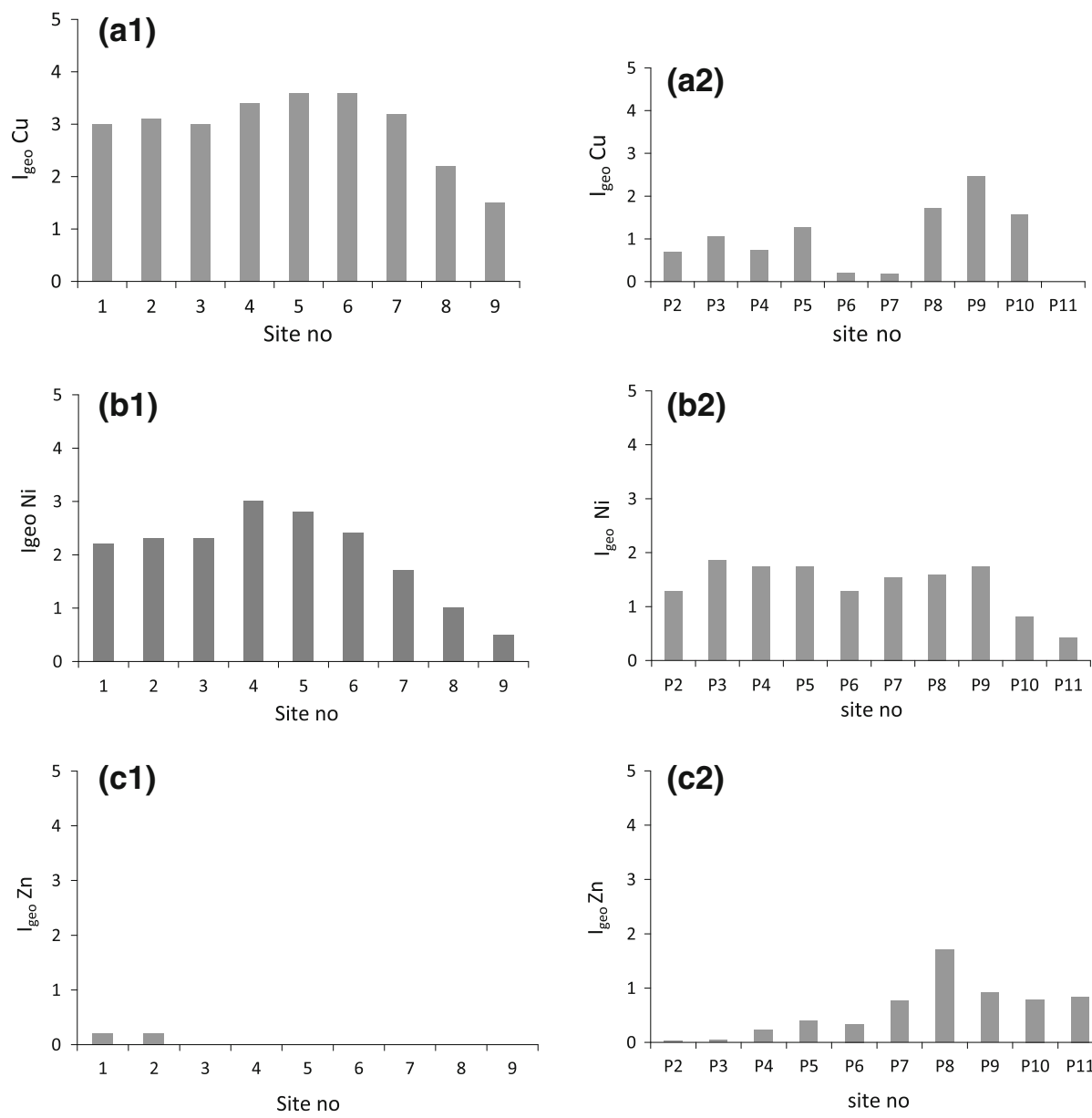

(Ekosse et al. 2003b) as well as PAM (Ekosse et al. 2004) that are definitely rich in $\mathrm{Cu}$. Copper and $\mathrm{Ni}$ contamination of soils around the $\mathrm{Cu}-\mathrm{Ni}$ mining environment could therefore be attributed to leachate from tailings dump and deposition of PAM from mineral processing. Increase in concentration of $\mathrm{Cu}$ in soils closer to the smelter/concentrator plant compared with those further away also justifies this explanation. In addition, $\mathrm{Cu}$ is not easily adsorbed at low $\mathrm{pH}$ due to competition with $\mathrm{Mg}^{2+}, \mathrm{Fe}^{3+}, \mathrm{H}^{+}$and $\mathrm{Al}^{3+}$ for sorption sites, which may explain the high concentrations in soils around the mine. Unlike $\mathrm{Cu}$ and $\mathrm{Ni}, \mathrm{Zn}$ concentration in $\mathrm{Cu}-\mathrm{Ni}$ orebodies and in their host rocks is geogenically low (Nsouli et al. 2004); and these low values have been reflected in its concentration in the studied soils from Selebi Phikwe mine.

The soils of the southern (P2, P3, P4, P5) and eastern (P6, P7, P8 and P9) corners of the landfill environment had higher concentrations of $\mathrm{Cu}$ than the northern corner. These areas lie on the slopes of the landfill according to geotechnical investigations of the site (Arup Botswana 1993). The chances of leachate generated by the decomposing waste in the landfill migrating towards these corners of the landfill are higher, which may explain the higher concentrations of $\mathrm{Cu}$ in the soils from these sites. Migration of leachate towards these sites is further justified by the identification of leachate plumes in a previous study by Bogatsu et al. (2000) along these corners of the landfill. Many products used by man for domestic, commercial and industrial purposes contain $\mathrm{Cu}$. Copper is therefore likely to be present in municipal solid waste and leachate originating from such waste (Christensen et al. 1996), justifying the higher concentration of $\mathrm{Cu}$ in these sites around the landfill. Soil profiles along the southern section especially around P4 and P5 showed elevated amounts of Ni. Nickel is used in alloys, electroplating, steel products, piping foil, brass, sheets and pipes which are disposed at the scrap metal and waste tyre sections of the landfill where these sampling sites were located (Fig. 1). Further to this, these sites are also located on the slopes of the landfill which dictates the direction of flow of any leachate generated in the landfill. P2 was located close to where building rubble was disposed which may explain the low concentration of $\mathrm{Zn}$, whereas the other profiles are found close to where refuse, scrap metal and waste tyres and other $\mathrm{Zn}$ containing substances are disposed. 
Fig. 4 Contamination factors of copper (a), nickel (b) and zinc (c) in soils within the mining (1) and landfilling (2) environments (a1)

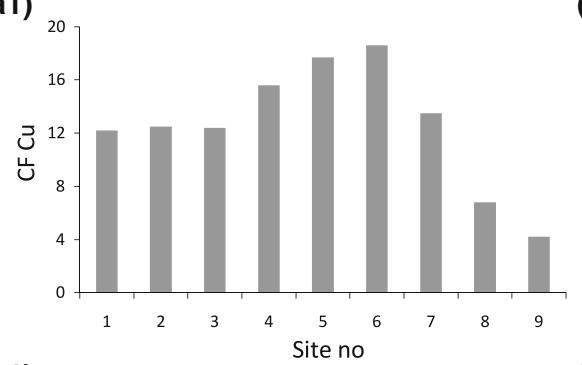

(b1)

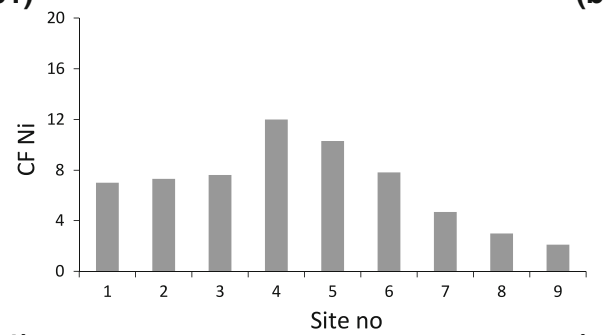

(c1)

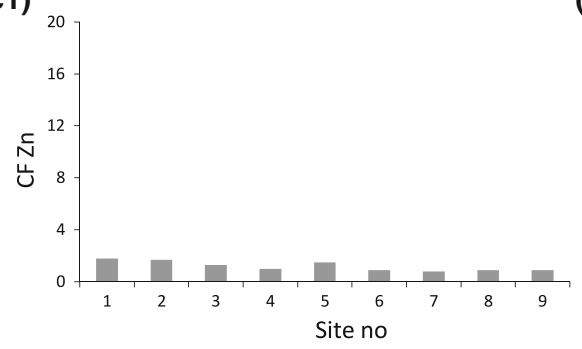

(a2)

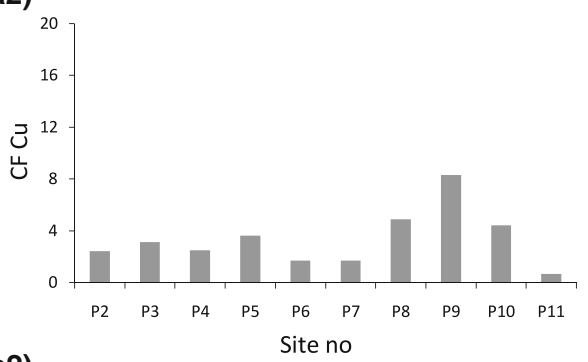

(b2)

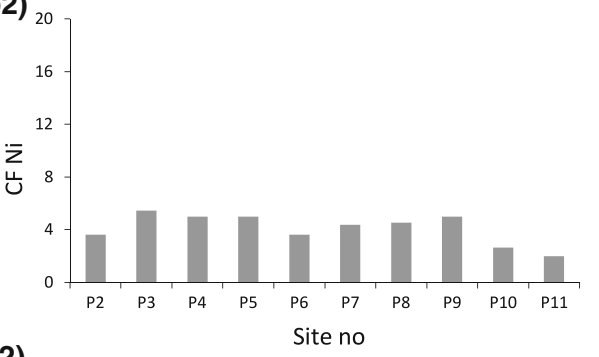

(c2)

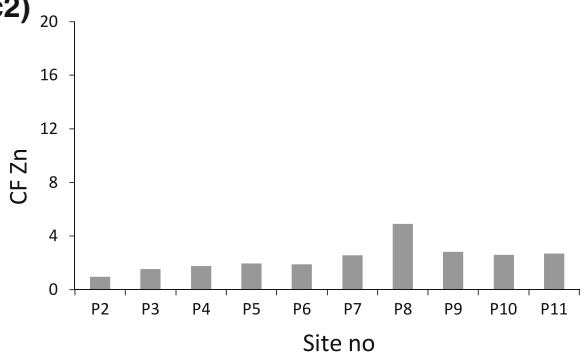

Pollution load index in the soils

The values obtained for pollution load index (PLI) of the sites within the precincts of the mining and landfilling environments indicated that both environments were polluted. The mining environment was more polluted (Fig. 5) than the landfill environment. At Selebi Phikwe, sites 4 and 5 , which were closest to the smelter/concentrator plant, were the most polluted whereas site 9 was the least (Fig. 5). Sites that were more polluted received more PAM as well as leachate from the tailings dump (Ekosse et al. 2003a, b). At the landfill environment, P8 and P9 were the most contaminated sites whereas P11 was the least contaminated. Leachate derived from refuse of municipal origin is likely to contain high concentrations of heavy metals like $\mathrm{Cu}, \mathrm{Ni}$ and $\mathrm{Zn}$ because these metals are used in manufacturing several commodities and products commonly used in homes. Moreover, soils in this site had the highest weight percent of clay and are composed of smectite and illite (Ngole et al. 2005) with a comparatively higher cation exchange capacity compared to the other sites where kaolinite and quartz were the most dominant minerals. These clay minerals are likely to have adsorbed these metals from the leachate resulting in higher concentrations in the soils. An explanation is hereby advanced for the high PLI values obtained for sites P8 and P9 within the landfilling environments (Fig. 5).

Ecological and environmental implications of heavy metals pollution in the studied areas

Tolerant levels for $\mathrm{Ni}$ in soils are between 4 and $80 \mathrm{mg} / \mathrm{kg}$ (Alloway and Ayres 1993; Suschka and Zielonka 1995), 2-100 $\mathrm{mg} / \mathrm{kg}$ for $\mathrm{Cu}$; and $10-300 \mathrm{mg} / \mathrm{kg}$ for $\mathrm{Zn}$ (Alloway 1990). These values could be very high in soils within $\mathrm{Cu}$ Ni mining environments. The levels obtained for concentrations of $\mathrm{Cu}$ and $\mathrm{Ni}$ in the soils of the Selebi Phikwe mining environment were higher than normal. Previous studies by Ekosse et al. (2003b) indicated that the soils around the Selebi Phikwe area were acidic. Under such acidic conditions, $\mathrm{Cu}, \mathrm{Ni}$ and many other heavy metals are more soluble (Brown et al. 1997). Copper and Ni toxicity in plants is therefore common in acid soils, because of the high levels of availability. High levels of $\mathrm{Cu}$ and $\mathrm{Ni}$ in the soils around the mining area may pose a hazard to plants. Values obtained for the heavy metals concentrations in 

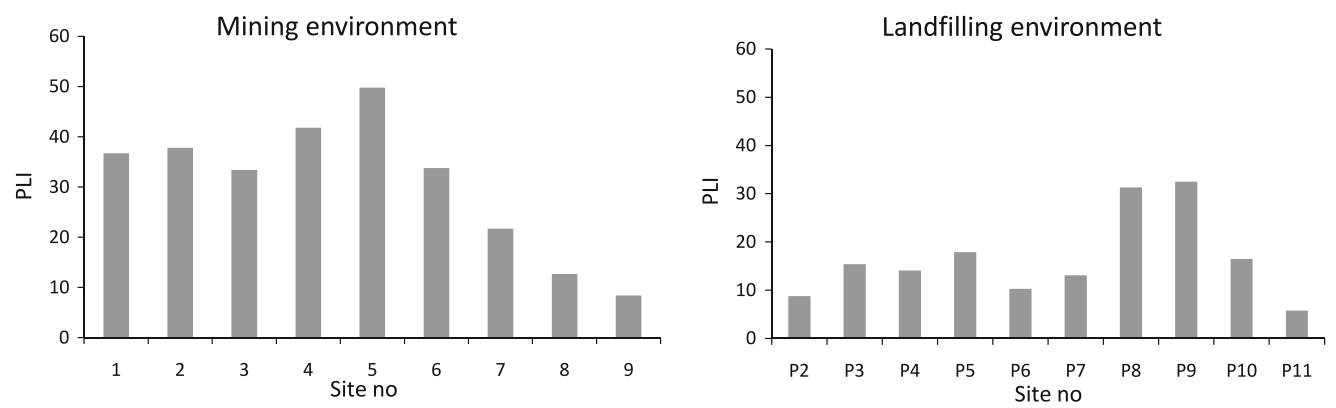

Fig. 5 Pollution load index of soils within the mining and landfilling environments

soils within the landfilling environment were within the normal soil ranges. No threat of $\mathrm{Zn}$ toxicity was presented by both the landfill and mining environment. Plants (Kabata-Pendias 1995; Brown et al. 1997) and soil dwelling animals (Ekschmit and Korthals 2006) have different tolerance levels for $\mathrm{Cu}, \mathrm{Ni}$ and $\mathrm{Zn}$. Concentrations of $\mathrm{Cu}$ and $\mathrm{Ni}$ in the soils around the mining environment above MAL especially in sites 1-8 may have had a negative effect on the diversity of plants in the area and biota inhabiting the soil. This was evident in the deterioration of vegetation cover in the mining environment leading to dead zones.

Imbalance in microbial population in the soil brought about by the high metal concentrations may also have affected decomposition processes in the soil with further consequence on organic matter dynamics and vegetation growth. Though the concentrations of all three metals around the landfill environment were below MAL values, leachate migration from the landfill environment may have created redox conditions in the soil due to saturation of soil pores. Under these conditions, fermentation could also have ensued resulting in acidification of the soils and modification of soil microbial population as well as the vegetation cover, with consequent imbalance in the soil ecosystem. Decrease in total microbial biomass due to landfill leachate has also been reported by Gordon et al. (1988). Uptake of $\mathrm{Cu}, \mathrm{Ni}$ and $\mathrm{Zn}$ by vegetation around both the mining and landfill environment were not determined but concentrations of $\mathrm{Cu}$ and $\mathrm{Ni}$ in soils around the mining environment may present a hazard to cattle grazing in the vicinity because higher than allowable concentrations of these metals in the soil could result in increased uptake by vegetation growing on these soils. In semi-arid environments like Botswana where water resources are limited leaching of these heavy metals from the soils into surface and groundwater may aggravate water supply challenges already faced by the country.

\section{Conclusion}

This paper focused on the application of $I_{\mathrm{geo}}, \mathrm{CF}$, and PLI in interpreting degrees of $\mathrm{Cu}, \mathrm{Ni}$ and $\mathrm{Zn}$ contamination and pollution of soils within the precincts of $\mathrm{Cu}-\mathrm{Ni}$ mining and urban landfilling environments. The findings depicted that soils at sites closer to mining activities are more loaded in $\mathrm{Cu}, \mathrm{Ni}$ and $\mathrm{Zn}$ concentrations than sites further away. The heavy metals concentrations within the landfilling environment reflected higher concentration levels of the metals at sites where leachate plumes had previously been identified. Mining and waste disposal activities have therefore resulted in elevated concentrations of $\mathrm{Cu}, \mathrm{Ni}$, and $\mathrm{Zn}$ in the soils within the mining and landfilling environments in Selebi Phikwe and Gaborone, respectively.

Acknowledgments The authors also wish to extend their sincere gratitude to all who assisted in promoting the present work.

\section{References}

Agunbiade FO, Fawale AT (2009) Use of Siam weed biomarker in assessing heavy metal contaminations in traffic and solid waste polluted areas. Int J Environ Sci Tech 6:267-276

Akoto O, Ephraim JH, Darko G (2008) Heavy metals pollution in surface soils in the vicinity of abundant railway servicing workshop in Kumasi Ghana. Int J Environ Sci Tech 2:359-364

Alloway BJ (1990) Heavy metals in soils. John Wiley and Sons, Inc, New York

Alloway BJ (2005) Copper-deficient soils in Europe. International Copper association. New York

Alloway BJ, Ayres DC (1993) Chemical principles of environmental pollution. Blackie Academic \& Professional, London

Alloway BJ, Ayres DC (1997) Chemical principles of environmental pollution. Chapman and Hall, London

Arup Botswana (1993) Gaborone solid Waste Disposal site development plan. Arup Botswana Consulting Engineers

Bai C, Reilly CC, Wood BW (2006) Nickel deficiency disrupts metabolism of ureides, amino acids, and organic acids of young pecan foliage. Plant Physiol 140:433-443

Barrie CT, Ludden JN, Green TH (2008) Geochemistry of volcanic rocks associated with $\mathrm{Cu}-\mathrm{Zn}$ and $\mathrm{Ni}-\mathrm{Cu}$ deposits in the Abitibi Subprovince. Econ Geol 88(6):1341-1358

Bhalotra YPR (1987) Elements of climate: climate of Botswana II. Department of Meteorological Services, Gaborone

Bogatsu Y, Atekwana E, Ekosse G, Atekwana E, Totolo O (2000) Hydrogeochemical impacts of the Gaborone Landfill on its surrounding subsurface environments. Bots Notes Rec 32:159-164

Brown PH, Welch RM, Cary EE (1987) Nickel: a micronutrient essential for higher plants'. Plant Physiol 85:801-803 
Brown S, Chaney R, Angle JS (1997) Surface liming and metal movement in soil amended with lime-stabilized biosolids. J Environ Qual 26:724-732

Christensen TH, Lehmann N, Jackson T, Holm PE (1996) Cadmium and nickel distribution coefficient for sandy aquifer materials. J Contamin Hydrol 24:75-84

Chuangcham U, Wirojanagud W, Charusiri P, Milne-Home W, Lertsirivoraku P (2008) Assessment of Heavy Metals from Landfill Leachate Contaminated to Soil: A Case Study of Kham Bon Landfill, Khon Kaen Province, NE Thailand. J Appl Sci 8(8):1383-1394

Ekosse G, van den Heever D, de Jager L, Totolo O (2003a) Environmental mineralogy of soils around the Selebi Phikwe Ni$\mathrm{Cu}$ mine area, Botswana. Int J Environ Stud 60(3):251-262

Ekosse G, Van den Heever DJ, de Jager L (2003b) Environmental physico-chemistry of tailings dump and soils around the Selebi Phikwe Ni-Cu mine area, Botswana. Int J Environ Stud 60(1):2

Ekosse G, Van den Heever DJ, de Jager L, Totolo O (2004) Environmental chemistry and mineralogy of particulate air matter around Selebi Phikwe copper-nickel plant, Botswana. Miner Eng 17(2):349-353

Ekosse G, Ngila JC, Forcheh N (2005) Multivariate analyses of heavy metals in soils and Colospermum mopane leaves around the Selebi Phikwe nickel-copper mine and smelter/concentrator plant, Botswana. J Appl Sci Environ Manage 9(1):177-185

Ekschmit K, Korthals GW (2006) Nematodes as Sentinels of heavy metals and organic toxicants in the soil. J Nematol 38(1):13-19

European Commission (2001) Pollutants in urban wastewater and sewage sludge. Office for Official Publications of the European Communities, Luxembourg

Gordon AM, McBride RA, Fisken AJ, Voroney RP (1988) Effect of landfill leachate spraying on soil respiration and microbial biomass in a northern hardwood forest ecosystem. Waste Manag Res 6(2): 141-148

Hakanson L (1980) An ecological risk index for aquatic pollution control: a sedimentological approach. Water Res 14(8):9751001

Ji Y, Feng Y, Wu J, Zhu T, Bai Z, Duan C (2008) Using geoaccumulation index to study source profiles of soil dust in China. J Environ Sci China 20:571-578

Kabata-Pendias A (1995) Agricultural problems related to excessive trace metal contents of soil. In: Salomons W, Förstner U, Mader P (eds) "Heavy metals (problems and solutions)". Springer, Berlin, pp 3-18

Kabata-Pendias A, Mukherjee AB (2007) Trace elements from soil to human. Springer, Berlin

Khupe JSN (1996) Water supply, sewage and waste management for Gaborone Botswana. AMBIO 25(2):138-143

Muller G (1969) Index of geoaccumulation in sediments of the Rhine River. Geol J 2:109-118

Ngole VM, Ekosse GE (2006) Status of minerals and heavy metals in the subsurface sediments around the Gaborone landfill, Botswana. Global J Pure Appl Sci 12(4):545-551

Ngole VM, Totolo O, Ekosse GE (2004) Physico-chemical and mineralogical characterization of subsurface sediments around
Gaborone landfill, Botswana. J Appl Sci Environ Manage $8(1): 49-53$

Ngole VM, Totolo O, Ekosse G (2005) Physico-chemical properties and clay fraction mineralogy of the subsurface sediments around the Gaborone landfill, Botswana. Bots J Earth Sci VI:14-19

Nicholls AM, Mal TK (2003) Effects of lead and copper exposure on growth of an invasive weed, lythrum salicaria 1. (purple loosestrife). Ohio J Sci 103:129-133

Nkoma JS, Ekosse G (1999) X-Ray diffraction study of chalcopyrite $\mathrm{CuFeS} 2$, pentlandite (Fe, Ni)9S8 and pyrrhotite Fe1-xS obtained from $\mathrm{Cu}-\mathrm{Ni}$ ore bodies. J Phy Condens Mat 11(1):121-128

Nsouli B, Darwish T, Thomas JP, Zahraman K, Roumie M (2004) Ni, $\mathrm{Cu}, \mathrm{Zn}$ and $\mathrm{Pb}$ background values determination in representative Lebanese soil using the thick target PIXE technique. Nuclear instruments and methods in physics research section B: beam interactions with materials and atoms, Proceedings of the Sixteenth International Conference on Ion Beam Analysis (219-220):181-186

Potenhaner L (1994) Botswana: Africa's last wilderness; the complete guide. Longman, Botswana, pp 47-49

Purves D (1973) Solid wastes and the environment-land. Inst Of Abstracted by CG Golueke. Compost Sci 14(5): 4-5

Schippers A, Kock D, Schwartz M, Böttcher ME, Vogel H, Hagger M (2007) Geomicrobiological and geochemical investigation of a pyrrhotite-containing mine waste tailings dam near SelebiPhikwe in Botswana. J Geochem Explor 92(2-3):151-158

Seshan BRR, Natesan U, Deepthi K (2010) Geochemical and statistical approach for evaluation of heavy metal pollution in core sediments in southeast coast of India. Int J Environ Sci Tech 7:291-306

Sheppard DS, Claridge GGC, Campbell IB (2000) Metal contamination of soils at Scott Base Antarctica. Appl Geochem 15:513-530

Singh AK, Hasnain SI, Banerjee DK (1999) Grain size and geochemical partitioning of heavy metals in sediments of the Damodar River-a tributary of the lower Ganga, India. Environ Geol 39(1):90-98

Šmuc NR, Vrhovnik P, Dolenec T, Serafimovski T, Tasev G, Dolenec M (2009) Assessment of the heavy metal contamination in the surficial sediments of Lake Kalimanci (Macedonia): a preliminary study. RMZ Mater Geoenviron 56:437-447

Soil Mapping and Advisory Service Project (1990) The soil map of Botswana. FAO/BOT/85/011

Suschka J, Zielonka U (1995) Some remarks on the contamination of the environment with heavy metals in a part of Poland. In: Salmons W, Frestener U, Mader P (eds) Heavy metals: problems and solutions. Springer, pp 393-401

Yruela I, Alfonso M, Barón M, Picorel R (2000) Copper effect on the protein composition of photosynthesis. Physiol Plant 110:551-557

Zhai M, Kampunzu HAB, Modisi MP, Totolo O (2003) Distribution of heavy metals in Gaborone urban soils (Botswana) and its relationship to soil pollution and bedrock composition. Environ Geol 45(2):171-180 